\title{
Estimated Prevalence and Number of PiMZ Genotypes of Alpha-I Antitrypsin in Seventy-Four Countries Worldwide
}

\author{
Cristina Martinez-González' \\ Ignacio Blanco $\mathbb{1 D}^{2}$ \\ Isidro Diego (iD ${ }^{3}$ \\ Patricia Bueno ${ }^{4}$ \\ Marc Miravitlles (iD ${ }^{5}$ \\ 'Pulmonology Department, University \\ Central Hospital of Asturias, Universidad \\ de Oviedo, Instituto de Investigación del \\ Principado de Asturias (ISPA), Oviedo, \\ Spain; ${ }^{2}$ Alpha l-Antitrypsin Deficiency \\ Spanish Registry (REDAAT), Spanish \\ Society of Pneumology and Thoracic \\ Surgery (SEPAR), Barcelona, Spain; \\ ${ }^{3}$ Materials and Energy Department, \\ School of Mining Engineering, Oviedo \\ University, Oviedo, Spain; ${ }^{4}$ Internal \\ Medicine Department, County Hospital \\ of Jarrio, Jarrio, Spain; ${ }^{5}$ Pneumology \\ Department, Hospital Universitari Vall \\ d'Hebron/Vall d'Hebron Research \\ Institute (VHIR), Vall d'Hebron Barcelona \\ Hospital Campus, CIBER de \\ Enfermedades Respiratorias (CIBERES), \\ Barcelona, Spain
}

Correspondence: Marc Miravitlles Pneumology Department, Hospital Universitari Vall d'Hebron, Pg. Vall d'Hebron II9-129, Barcelona, 08035, Spain

Email marcm@separ.es
Background: The $\alpha-1$ antitrypsin (AAT) protease inhibitor PiMZ is a moderately deficient genotype, until recently considered of little or negligible risk. However, a growing number of studies show that MZ carriers have an increased risk of developing lung and liver diseases, if exposed to smoking or other airborne or industrial pollutants, and hepatotoxic substances.

Methods: We used the epidemiological studies performed to determine the frequencies of PiM and PiZ worldwide, based on the following criteria: 1) samples representative of the general population; 2) AAT phenotyping or genotyping characterized by adequate methods, including isoelectric focusing and polymerase chain reaction; and 3) studies with reliable results assessed with a coefficient of variation calculated from the sample size and $95 \%$ confidence intervals, to measure the precision of the results in terms of dispersion of the data around the mean.

Results: The present review reveals an impressive number of MZs of more than 35 million in 74 countries of the world with available data. Seventy-five percent of them are people of Caucasian European heritage, mostly living in Europe, America, Australia and New Zealand. Twenty percent of the remaining MZs live in Asia, with the highest concentrations in the Middle East, Eastern, Southern, and South-eastern regions of the Asian continent. The remaining five percent are Africans residing in Western and Eastern Africa.

Conclusion: Considering the high rate of smoking, the outdoor and the indoor air pollution from solid fuels used in cooking and heating, and the exposure to industrial dusts and chemicals in many of these countries, these figures are very worrying, and hence the importance of adequately assessing MZ subjects, recommending them rigorous preventive measures based on the adoption of healthy lifestyles, including avoidance of smoking and alcohol.

Keywords: SERPINA1, $\alpha 1$-antitrypsin, PiMZ genotype, genetic epidemiology, COPD, tobacco smoking, inverse distance weighted interpolation, IDW, geographic information system, GIS

\section{Introduction}

Human alpha-1 antitrypsin (AAT) is a circulating glycoprotein encoded by the SERPINA1 gene, mainly synthesized and secreted by the liver. Its physiological function is to neutralize the excess of free elastase and proteinase 3 (PR3) from activated neutrophils to avoid excessive degradation of elastin and collagen IV of connective tissue of the lungs. ${ }^{1}$

Alpha-1 antitrypsin deficiency (AATD) is a genetic condition, transmitted by autosomal codominant inheritance, caused by mutations of the SERPIN $A 1$ gene, of which more than 120 variants have been identified, and about $40 \%$ of them can 
cause AATD. ${ }^{2}$ The vast majority of SERPIN $A 1$ genotypes result from combinations between the normal protease inhibitor (Pi) $\mathrm{M}$ allele and the most frequent deficiency alleles PiS and PiZ, namely PiMM, PiMS, PiSS, PiMZ, PiSZ and PiZZ, which roughly express $100 \%, 80 \%, 60 \%$, $55 \%, 40 \%$ and $15 \%$ of serum AAT, respectively. ${ }^{3,4}$

The $\mathrm{Z}$ allelic variant (Glu342Lys) is characterized by the production of a defective protein with marked conformational changes causing the formation of AAT-Z polymers that are retained within hepatocytes without being secreted into the blood, and a loss of their inhibitory capacity of $80-90 \%{ }^{5}$ In clinical practice, severe AATD is associated with PiZZ genotypes in more than $95 \%$ of the cases, and it can manifest clinically as infantile cholestasis $(\sim 11 \%)$, liver fibrosis or cirrhosis at all ages of life ( $\sim 30 \%$ ), chronic obstructive pulmonary disease (COPD) ( $\sim 60-80 \%$ ), and much less frequently as neutrophilic panniculitis, granulomatosis with polyangiitis and hepatocarcinomas, although between a third or a half of ZZ subjects not exposed to risk factors (especially tobacco smoke) may not express any of these diseases throughout their life. ${ }^{1-4,6}$

After the discovery of lung emphysema associated with severe AATD by Laurell and Erickson ${ }^{7}$ more than half a century ago, the PiMZ genotype has been considered by some authors as an AAT moderately deficient genotype with little or no risk. ${ }^{8-11}$ However, later studies indicated that while non-smoking MZs are not at increased risk for lung disease, $\mathrm{MZ}$ smokers have an increased risk of developing COPD. ${ }^{12-27}$ In addition, the available evidence indicates that although the PiMZ genotype is not associated with an increased risk for childhood liver disease, ${ }^{28}$ however in adults a surprisingly high prevalence of this genotype has been found in several series of patients with end-stage liver disease on transplant lists. ${ }^{29-32}$ Two decades ago, de Serres advanced that the world population of MZs exceeded 25 million individuals, mostly Caucasians of European heritage, although also some individuals of other races. ${ }^{33}$ Therefore, although probably only a small proportion of MZ individuals could develop of AATD-related diseases, its large number generates concerns about their potential to become an important public health problem, especially in individuals with unhealthy lifestyles and a propensity for excessive tobacco and alcohol consumption.

The objective of the present study is to update the epidemiological data about prevalence and number of PiMZ genotypes, as well as smoking rates, in 74 countries of the world with available data, to provide some reliable information to the healthcare professionals, so that they can offer their patients appropriate genetic advice and recommend them preventive measures, such as the elimination of smoking (both active and passive), vaccination against viral hepatitis, avoidance of exposure to environmental pollutants, and withdrawal of alcohol other hepatotoxic substances.

\section{Methods}

The methodology used in the present study to obtain the prevalence and number of PiMZs was similar to the ones previously used by the authors to obtain the prevalence and number of PiZZ and PiSZ genotypes in the world. ${ }^{34,35}$ Briefly, we used the epidemiological studies performed to determine the frequencies of PiM and PiZ in the healthy control samples worldwide, based on the following criteria: 1) samples representative of the general population; 2) AAT phenotyping or genotyping characterized by adequate methods, including isoelectric focusing (IEF) and polymerase chain reaction (PCR); and 3) selection of studies with reliable results assessed with a coefficient of variation calculated from the sample size and $95 \%$ confidence intervals, to measure the precision of the results in terms of dispersion of the data around the mean. The following studies were excluded from the analysis: 1) cohort studies of patients with AATD-related diseases (eg, COPD, liver cirrhosis, etc.), 2) screening studies in which phenotypes were determined only in samples with AAT concentrations below any given cut-off point. The manuscripts were obtained through a variety of sources, particularly searches of the peer-reviewed literature from 1965 to 2021 on PubMed, Embase, and Google Scholar databases. Additional relevant studies were obtained by searching the bibliographies of the retrieved articles (Supplementary material).

Data on populations and smoking rates were obtained from the CIA's World Factbook 2021 (https://www.cia. gov/the-world-factbook), and from the US Census Bureau World Population Review 2021 (https://worldpopu lationreview.com/country-rankings/smoking-rates-bycountry).

The MZ prevalence values of the 74 selected countries were used to develop maps using a geographic information system (GIS) of an inverse distance-weighted (IDW) interpolation method. This methodology has been described in detail by the authors previously. ${ }^{34-36}$ In brief, the GIS-IDW interpolation computer program used the prevalence rates combined with the geographical coordinates of the places where studies were conducted, in order to create raster 
images with data encoded by pixel values and locations. Interpolation maps have the important advantage of being able to provide visual data from regions lacking studies, based on the real data from other neighbouring regions. We applied a raster matrix with interpolated values generated from the eight nearest pixel points using weighted averages, a power (p) of 4 , and a resolution of 0.1 degrees. With this approach, maps displayed the prevalence data by a contrasting blue-red scale, with the darker colours at each end, representing "the more negative" (blue) and "the more positive" (red). Since the different colours correspond to numerical values, they can easily be converted into quantitative data with the naked eye.

In addition, given that smoking is the most important known non-genetic risk factor for the development of COPD in MZs, a GIS-IDW world map of smoking rates was created with data from 127 countries on all continents, provided by the US Census Bureau World Population Review 2021.

As these strategies involved a pooled analysis of published data, ethical approval and informed consent were not required.

\section{Results}

Data on prevalence and number of MZs and smoking rates from 74 of the 195 sovereign countries in the world, with a population of 5,854,304,836 subjects (out of a total of $7,577,130,400$ people on earth), were analysed. Twenty-five of these countries belonged to Europe, twenty-two to America, fifteen to Asia, ten to Africa, and two to Oceania (-4).

A total of 180 studies ( 90 from Europe, 41 from America and Caribbean islands, 15 from Africa, 25 from Asia, 8 from Australia, and 1 from New Zealand) were selected. These studies included a total of 191,953 subjects, distributed as follows: 82,118 in America and Caribbean; 76,612 in Europe; 21,353 in Asia; 6,839 in Australia and New Zealand, and 5,031 in Africa (Tables 1-4).

The mean smoking rate in these countries was as follows: $22.9 \%$ in Europe, $21.4 \%$ in Asia, $15.2 \%$ in America and Africa, and $14.8 \%$ in Australia and New Zealand (Table 1).

The mean prevalence of PiMZ was $1 \mathrm{MZ}$ every 32 subjects (1:32) in Australia-New Zealand, 1:58 in Europe, and 1:91 in America, with large differences between countries and regions, even in a same continent. In Asia and Africa, the global mean prevalence could not be calculated with precision due to the lack of sufficient studies and the absence of MZ genotypes in some cohorts of several countries (Tables 1-4).

The estimated total number of MZs was 35,164,351 subjects, distributed as follows: 13,804,800 in the Americas, 11,042,230 in Europe, 7,939,711 in Asia, $1,540,452$ in Africa, and 837,158 in Australia-New Zealand (Tables 1-4).

The GIS-IDW interpolation map of Figure 1A shows the estimated prevalence of MZs in the 74 selected countries and also provided graphical information of the regions lacking studies, interpolating real data from studies conducted "in situ" to the neighbouring areas without data. Areas shaded in deep red, indicative of very high prevalence (between $<1: 80$ and $\leq 1: 40$ ), were visible in practically the entire European continent, especially in European Russia, Balkan Peninsula, Iberian Peninsula, Scandinavian Peninsula and Central Europe. High or very high prevalence could also be seen in red-shaded areas of the easternmost part of Africa belonging to the "Horn of Africa"; the Arabian Peninsula; Northeast Asia, including the Korean Peninsula; and Indochina. Prevalences were also

Table I Estimated PiMZ Mean Prevalence, Total Number, and Smoking Rate in 74 Countries of the World

\begin{tabular}{|c|c|c|c|c|}
\hline $\begin{array}{l}\text { Number of Countries Studied for Each Continent } \\
\text { (n) and Total Population }\end{array}$ & $\begin{array}{l}\text { Cohorts Number } \\
\text { (Sample Size) }\end{array}$ & $\begin{array}{c}\text { Mean } \\
\text { Smoking } \\
\text { Rate (\%) }\end{array}$ & $\begin{array}{c}\text { PiMZ Mean } \\
\text { Prevalence }(\mathbf{I} / \mathbf{x})\end{array}$ & $\begin{array}{c}\text { Estimated } \\
\text { Number of PiMz }\end{array}$ \\
\hline Europe $(n=25) .598,884,590$ & $90(76,612)$ & 22.9 & $1: 58$ & $1 \mathrm{I}, 042,230$ \\
\hline America $(n=22) \cdot 999,832,319$ & $4 I(82,118)$ & 15.2 & $1: 9 \mid$ & $13,804,800$ \\
\hline Africa $(n=10) \cdot 473,963,529$ & $15(5,031)$ & 15.2 & $1: 125^{\mathrm{T}}$ & $1,540,452$ \\
\hline Asia $(n=15) \cdot 3,750,822,983$ & $25(21,353)$ & 21.4 & $\mathrm{I}: 337^{+}$ & $7,939,711$ \\
\hline Australia and New Zealand $(n=2) .30,801,415$ & $9(6,839)$ & 14.8 & $1: 32$ & 837,158 \\
\hline Total: $n=74.5,854,304,836$ & $180(191,953)$ & 17.9 & I:I 29 & $35,|64,35|$ \\
\hline
\end{tabular}

Notes: TThis value results from the mean of the prevalence values of Morocco, Cape Verde, Nigeria and Somalia, since in the selected six remaining African countries there is no MZ and its prevalence is I/0 (that is, I/infinite). ${ }^{+}$TThis value results from the mean of the prevalence values of Iran, Kazakhstan, Japan, Malaysia, South Korea, Thailand, Pakistan and India, since in the remaining selected Asian countries there is no $M Z$ and its prevalence is $1 / 0$ (that is, I/infinite).

Abbreviation: $\mathrm{Cl}$, confidence interval. 


\begin{tabular}{|c|c|c|c|c|c|c|c|c|c|c|c|c|c|c|c|c|c|c|c|c|c|}
\hline 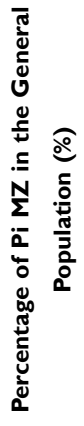 & 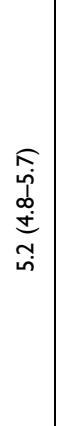 & 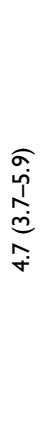 & $\begin{array}{l}\sigma \\
\dot{a} \\
\bar{d} \\
\dot{\rho} \\
\underline{m}\end{array}$ & 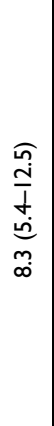 & 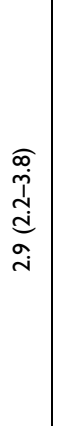 & $\begin{array}{l}\widehat{\bar{\square}} \\
\stackrel{0}{\dot{m}} \\
\stackrel{m}{n} \\
\stackrel{m}{m}\end{array}$ & 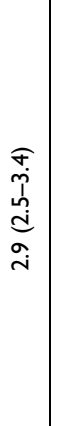 & $\overline{\dot{r}}$ & 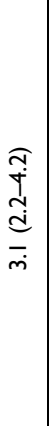 & 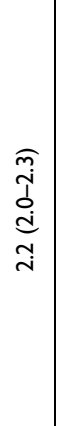 & 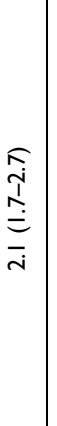 & $\begin{array}{l}\widehat{m} \\
\stackrel{i}{d} \\
\stackrel{d}{d} \\
\stackrel{\sim}{i}\end{array}$ & 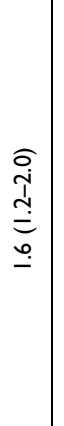 & 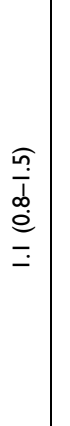 & 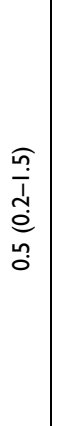 & $\underline{a}$ & 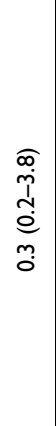 & 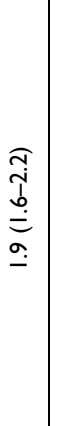 & $\begin{array}{l}\widehat{a} \\
\dot{b} \\
\dot{b} \\
\stackrel{0}{0} \\
\infty \\
0\end{array}$ & 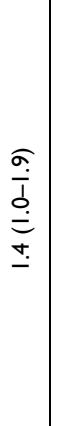 & $=$ \\
\hline 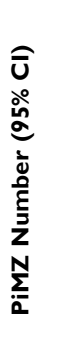 & 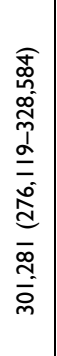 & 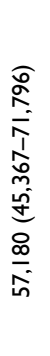 & 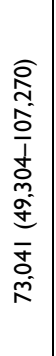 & 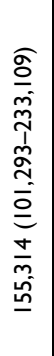 & 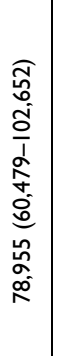 & 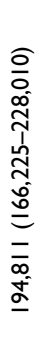 & 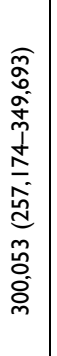 & $\begin{array}{l}\stackrel{\omega}{0} \\
\stackrel{0}{0} \\
\underline{0} \\
\underline{-}\end{array}$ & 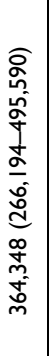 & 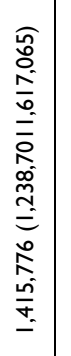 & 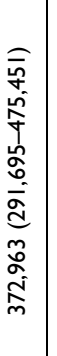 & 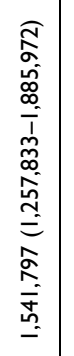 & 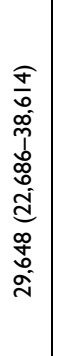 & 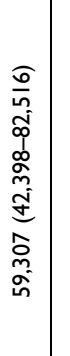 & 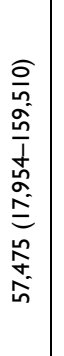 & 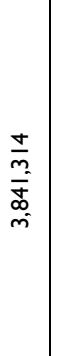 & 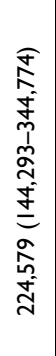 & 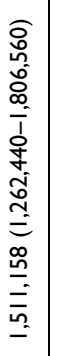 & 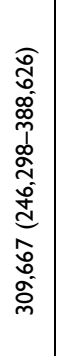 & 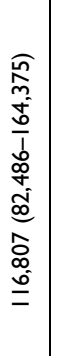 & 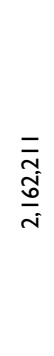 \\
\hline
\end{tabular}

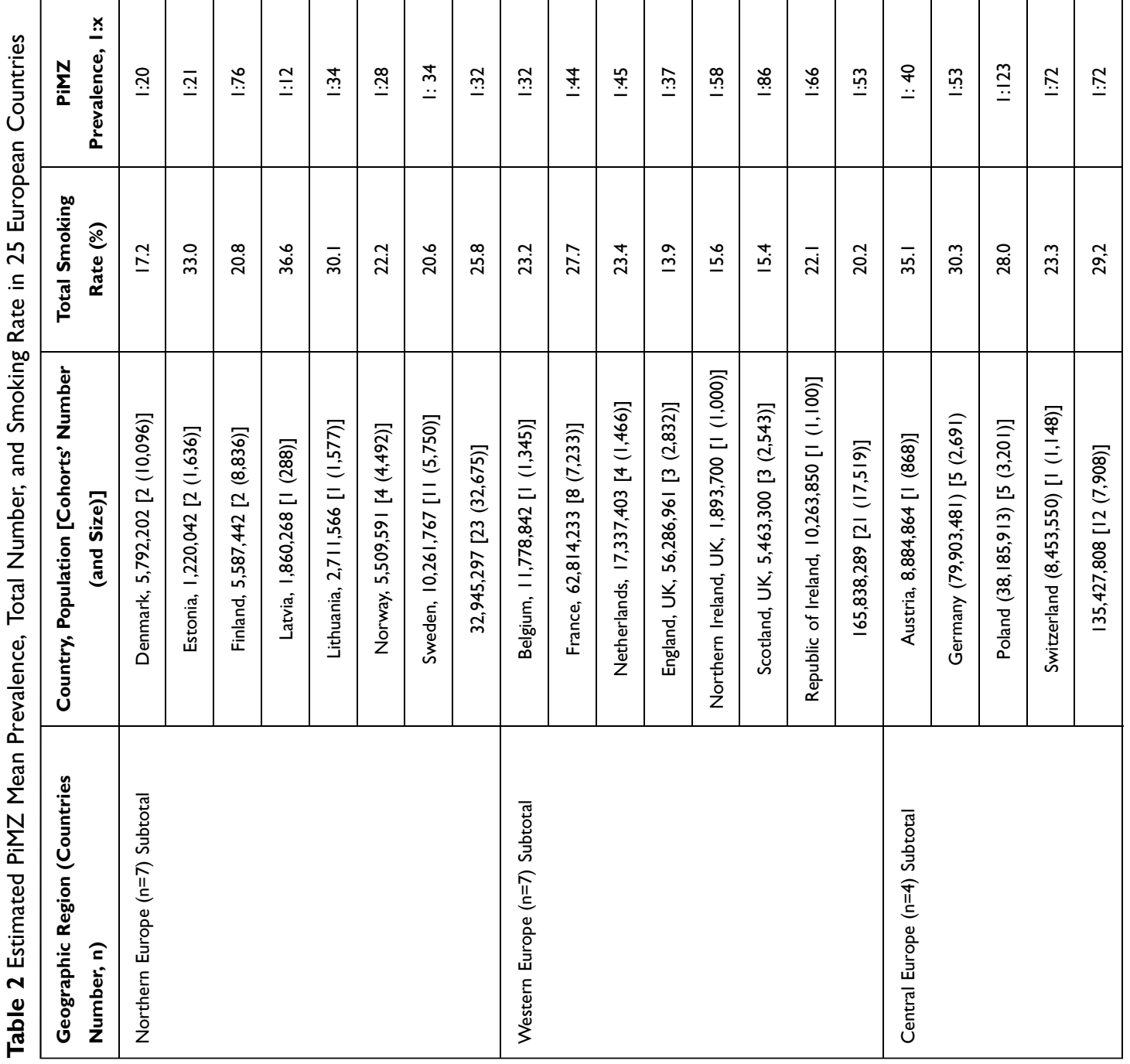




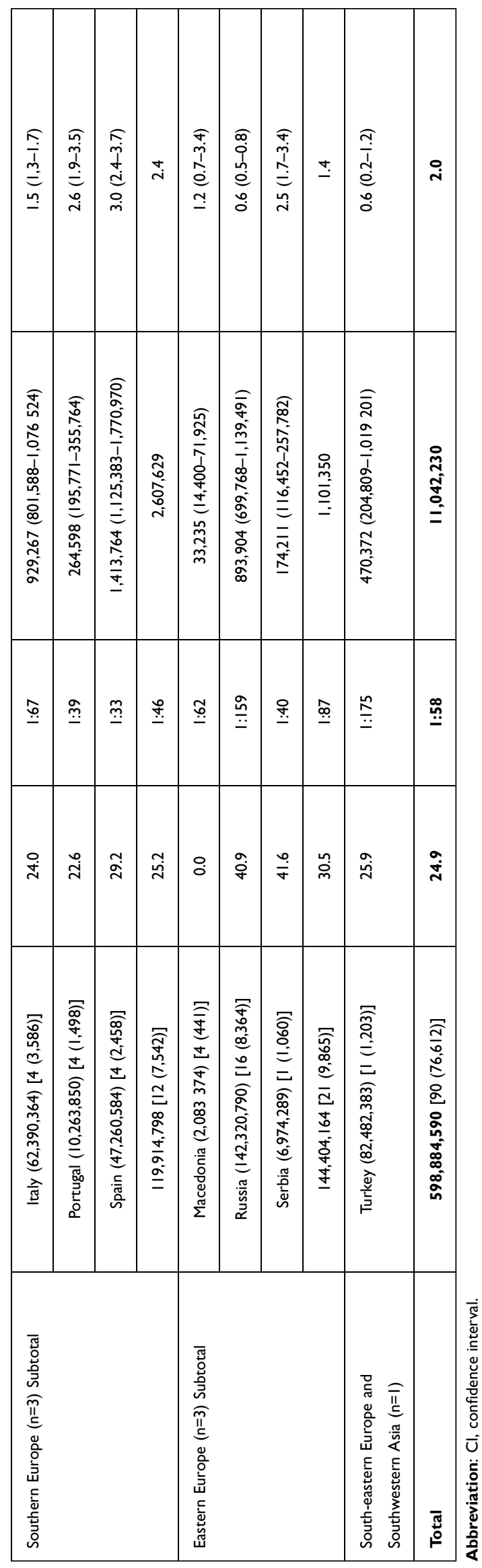

high in coastal areas of Eastern and South-eastern Australia and New Zealand. The Midwest of North America showed dark red shading, indicative of high prevalence, and the rest of the American continent, Central America, Caribbean islands and South America were shaded in light red or brown, indicative of moderate prevalence. Extensive regions of central, eastern and southern Africa, as well as some of southern, eastern, and southeastern Asia were coloured in blue, indicative of low MZ prevalence.

The GIS-IDW interpolation map of Figure 1B shows the smoking rates in 127 countries of the world and also provided visual information of the areas lacking data interpolating real data provided by studies conducted "in situ" to the neighboring areas without data. The blue-red scale ranges from $0 \%$ to $45 \%$. There are high or very high rates in large, red-shaded areas across most Europe; Asia; north of Africa; southern cone of South America; eastern and south-eastern Australia and New Zealand. In North America and West Africa, the rates are moderate (light red shades). Values are low (represented by blue shades) in the northern countries of South America and Central America; and in East, West and South Africa. In general, American and African countries have lower smoking rates than Europe and Asia.

Comparing the MZ prevalence and the smoking GISIDW interpolation maps, it can be seen that high prevalence of MZ coincides with high smoking rates in Europe; Western Asia; North America; southern cone of South America; Australia and New Zealand. However, the areas of the East and West Africa and the northern countries of South America, with high prevalence of MZ, have low rates of smoking.

\section{Discussion}

The PiMZ-associated risk to develop COPD has been described as an increase in active smokers and ex-heavy smokers, but in the absence of smoking or exposure to other air environmental pollutants, its risk has been quantified as low. ${ }^{12-26}$ The risk of emphysema is more evident in case-control than in population-based studies, due to differences in design and statistical power of some studies. Family studies also show an increased risk of emphysema in MZ smokers. ${ }^{27}$ In addition, the few published studies on the effects of excessive exposure to airborne and industrial pollutants have reported an abnormal deterioration of lung function in MZ exposed to air pollutants used in agriculture, mineral dust, gas, and fumes. ${ }^{37-40}$ Finally, its causal 


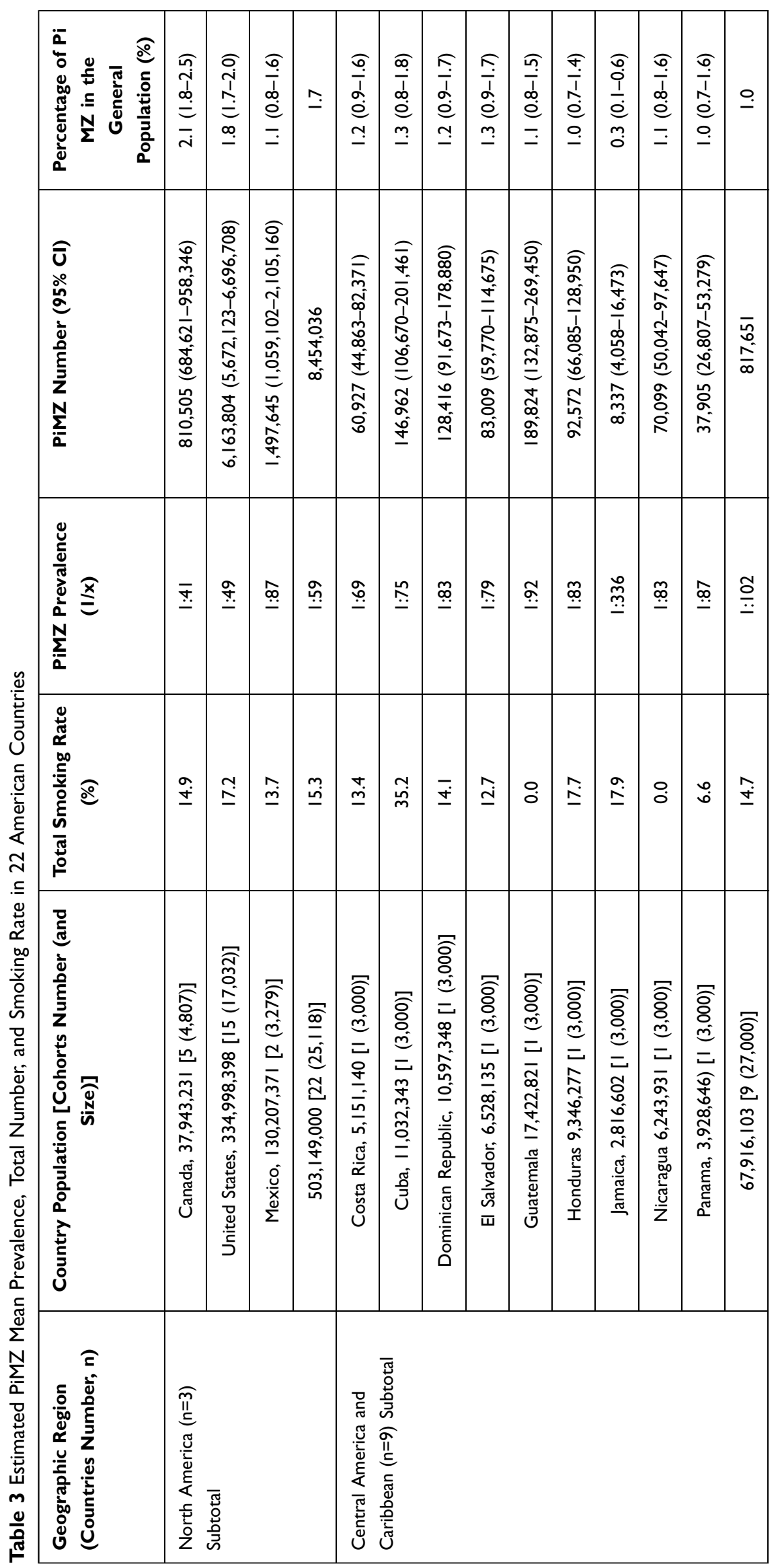




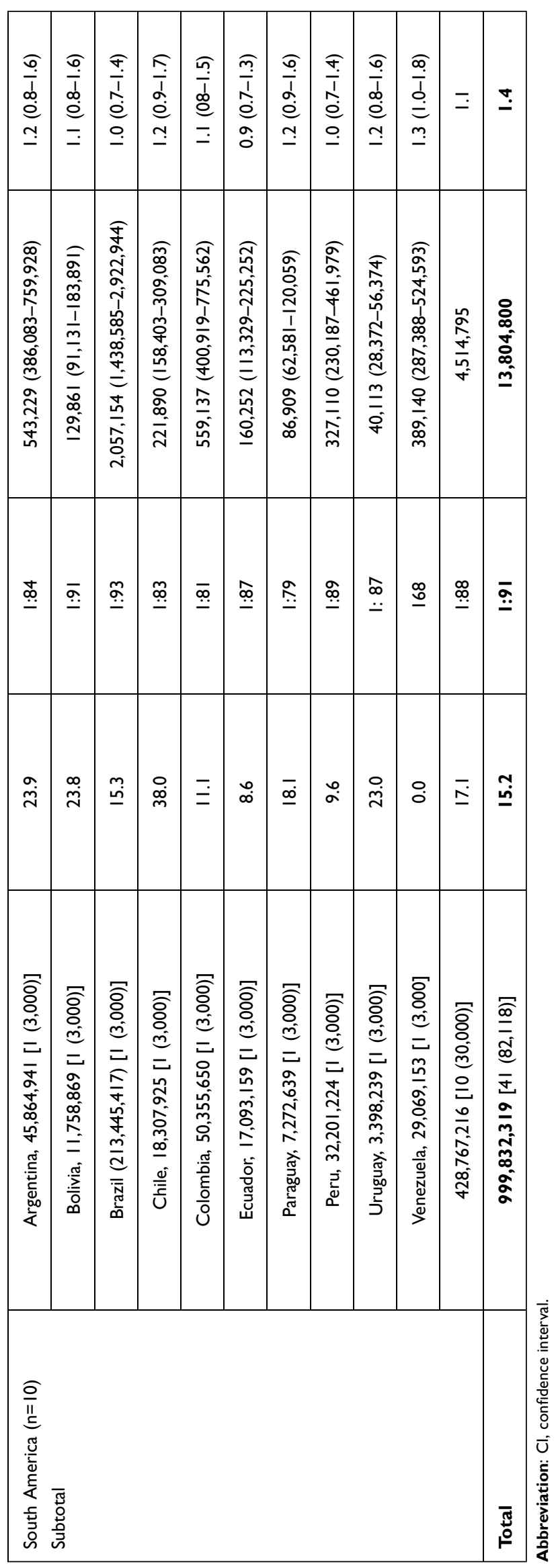




\begin{tabular}{|c|c|c|c|c|c|c|c|c|c|c|c|c|c|c|}
\hline 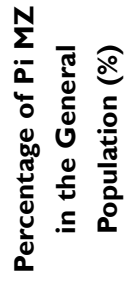 & 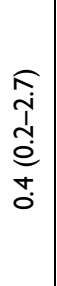 & $\begin{array}{l}\text { ñ } \\
0 \\
0 \\
0 \\
0 \\
0\end{array}$ & $\begin{array}{l}\widehat{\bar{p}} \\
\dot{0} \\
\dot{0} \\
\stackrel{0}{0}\end{array}$ & 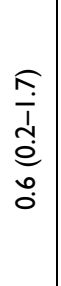 & $\begin{array}{l}\widehat{o} \\
i \\
i \\
0 \\
0 \\
0 \\
0\end{array}$ & $\begin{array}{l}\widehat{\infty} \\
0 \\
0 \\
0 \\
0 \\
0 \\
0\end{array}$ & $\begin{array}{l}\widehat{T} \\
\overline{1} \\
0 \\
0 \\
0 \\
0\end{array}$ & 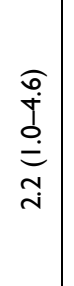 & $\begin{array}{l}o \\
0 \\
0 \\
0 \\
0 \\
0 \\
0\end{array}$ & $\mid$\begin{tabular}{l|}
$\sigma$ \\
0 \\
0 \\
1 \\
0 \\
0 \\
0 \\
0
\end{tabular} & mo. & 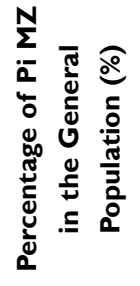 & $\begin{array}{l}\widehat{\hat{i}} \\
\infty \\
0 \\
\stackrel{0}{m} \\
\underline{i}\end{array}$ & $\mid \begin{array}{c}\frac{n}{10} \\
\frac{1}{1} \\
0 \\
\vdots \\
0 \\
0\end{array}$ \\
\hline 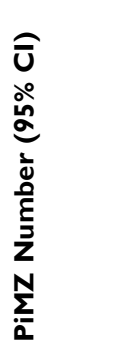 & $\begin{array}{l}0 \\
0 \\
0 \\
\infty \\
0 \\
0 \\
\infty \\
\infty \\
0 \\
0 \\
\infty \\
0 \\
0 \\
\underline{1} \\
\underline{0}\end{array}$ & 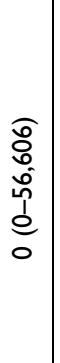 & 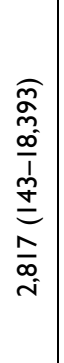 & 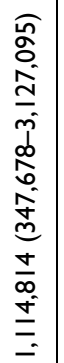 & 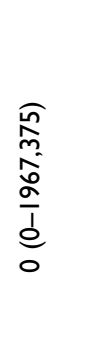 & $\begin{array}{l}\hat{E} \\
\hat{0} \\
\hat{0} \\
0 \\
0 \\
0\end{array}$ & 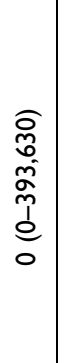 & 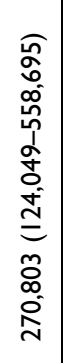 & 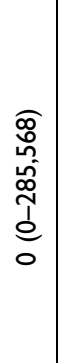 & 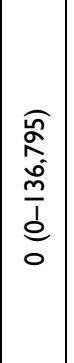 & 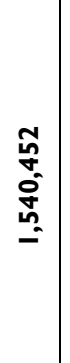 & 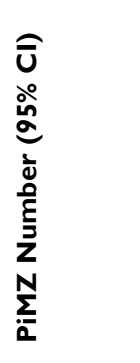 & 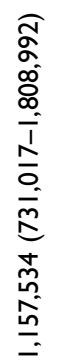 & 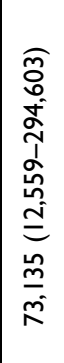 \\
\hline 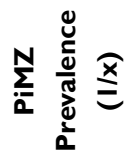 & $\stackrel{\stackrel{Q}{\oplus}}{=}$ & $\stackrel{\circ}{\longrightarrow}$ & 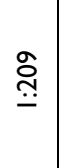 & $\underline{\underline{0}}$ & $\stackrel{\circ}{\underline{P}}$ & 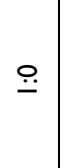 & $\stackrel{\circ}{\underline{.}}$ & 草 & 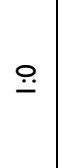 & $\stackrel{\circ}{\underline{P}}$ & $\stackrel{\stackrel{\sim}{\sim}}{\ddot{-}}$ & 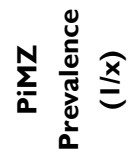 & 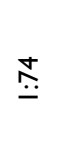 & 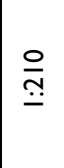 \\
\hline 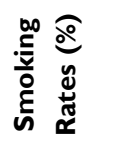 & $\vec{\sim}$ & 悹 & $\stackrel{\infty}{\stackrel{\infty}{\mathbf{I}}}$ & న & 음 & ்ָ & 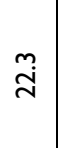 & $\stackrel{\circ}{\circ}$ & $\stackrel{+}{\dot{ \pm}}$ & $\begin{array}{l}\text { ळ. } \\
\underline{\infty}\end{array}$ & $\stackrel{\text { }}{\underline{n}}$ & 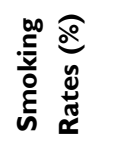 & $\bar{\Xi}$ & 通 \\
\hline 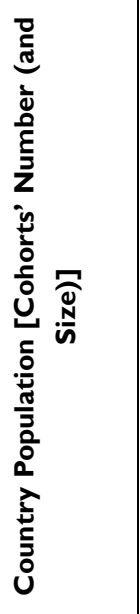 & 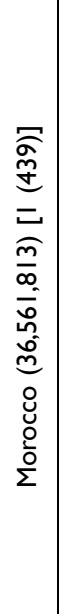 & 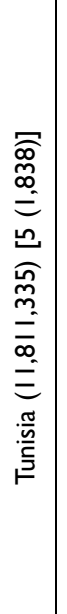 & 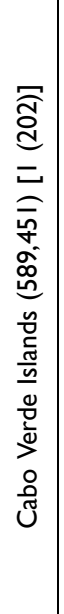 & 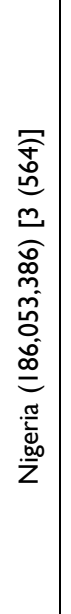 & 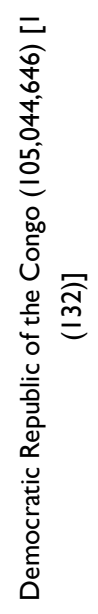 & 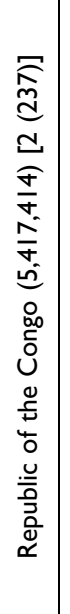 & 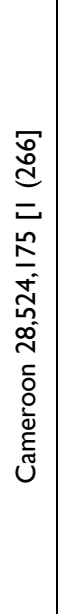 & 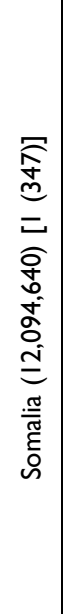 & 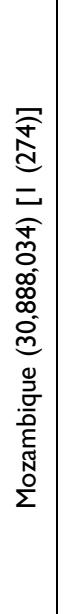 & 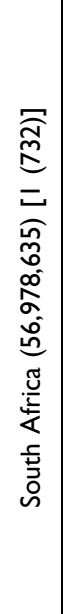 & 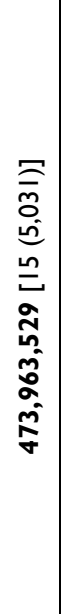 & 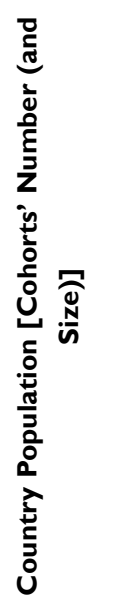 & 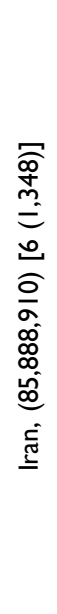 & 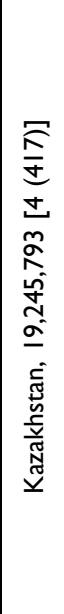 \\
\hline 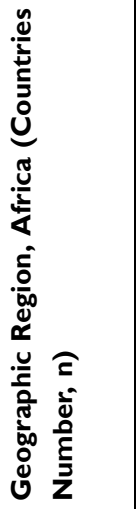 & 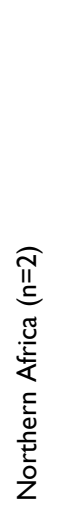 & & 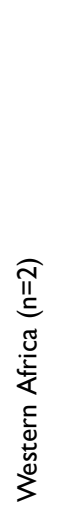 & & 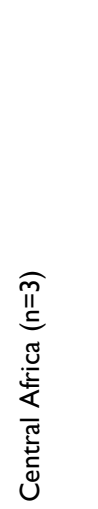 & & & 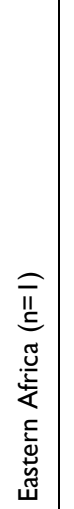 & 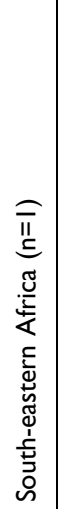 & 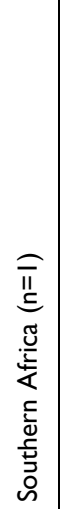 & 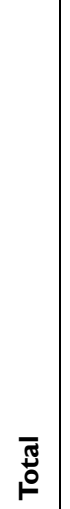 & 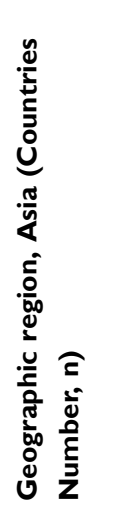 & 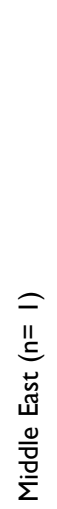 & 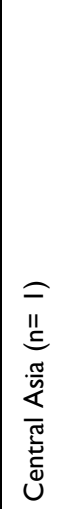 \\
\hline
\end{tabular}




\begin{tabular}{|c|c|c|c|c|c|c|c|c|c|c|c|c|c|c|c|c|c|c|c|}
\hline $\begin{array}{l}\text { - } \\
1 \\
0 \\
0 \\
0 \\
0\end{array}$ & $\begin{array}{l}\pi n \\
0 \\
0 \\
0 \\
0 \\
0 \\
0\end{array}$ & $\begin{array}{l}0 \\
0 \\
0 \\
0 \\
0 \\
0 \\
0\end{array}$ & $\begin{array}{l}0 \\
0 \\
0 \\
0 \\
0 \\
0 \\
0\end{array}$ & $\begin{array}{l}\text { R. } \\
0 \\
0 \\
0 \\
0 \\
0 \\
0\end{array}$ & 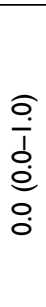 & $\begin{array}{l}\frac{\pi}{0} \\
\vdots \\
0 \\
0 \\
0 \\
0\end{array}$ & $\begin{array}{l}\text { K. } \\
0 \\
0 \\
0 \\
0 \\
0 \\
0\end{array}$ & 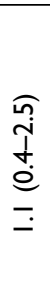 & 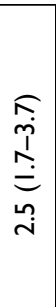 & I & $\begin{array}{l}\sqrt{n} \\
\text { ì } \\
0 \\
0 \\
0 \\
0\end{array}$ & $\begin{array}{l}\tilde{m} \\
\stackrel{n}{1} \\
\stackrel{\omega}{0} \\
\underline{m}\end{array}$ & 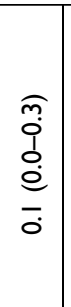 & 1 & ก̃ & 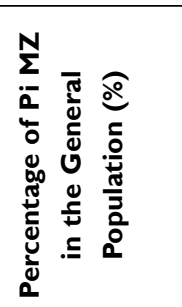 & 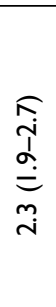 & 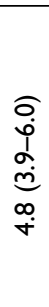 & $\stackrel{n}{m}$ \\
\hline $\begin{array}{l}\sqrt{n} \\
\text { م } \\
\text { i } \\
\text { d } \\
0\end{array}$ & $\begin{array}{l}\widehat{o} \\
0 \\
0 \\
\infty \\
0 \\
m \\
\overline{0} \\
0 \\
0\end{array}$ & $\begin{array}{l}\widehat{F} \\
\sigma \\
0 \\
\frac{0}{1} \\
\frac{1}{n} \\
\frac{1}{5} \\
0 \\
0 \\
\frac{m}{\sigma}\end{array}$ & $\begin{array}{l}\frac{E}{n} \\
\frac{a}{N} \\
\frac{n}{n} \\
\frac{n}{n} \\
\frac{m}{m} \\
\frac{m}{\infty}\end{array}$ & 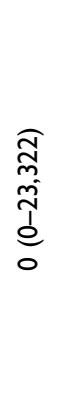 & 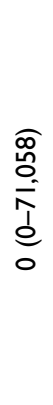 & 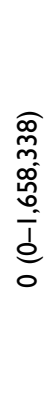 & 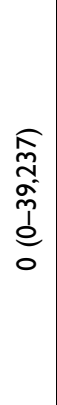 & 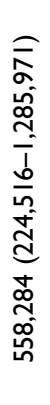 & 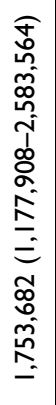 & 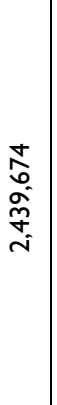 & $\begin{array}{l}\widehat{\infty} \\
\frac{\infty}{+} \\
\hat{i} \\
d \\
0\end{array}$ & 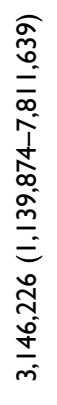 & 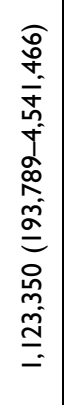 & \begin{tabular}{l}
$\stackrel{0}{2}$ \\
$\alpha$ \\
\multirow{2}{*}{} \\
\multirow{\sigma}{*}{}
\end{tabular} & $\begin{array}{l}\bar{\Sigma} \\
\text { aे } \\
\alpha \\
\alpha\end{array}$ & 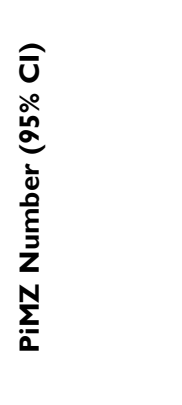 & 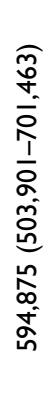 & 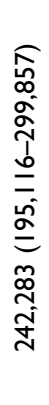 & 足 \\
\hline 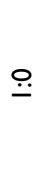 & $\stackrel{\circ}{\underline{P}}$ & $\frac{r}{0}$ & 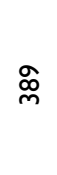 & $\stackrel{\circ}{\underline{.}}$ & 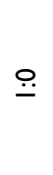 & $\stackrel{\circ}{\underline{.}}$ & $\stackrel{\circ}{=}$ & a & q & 1 & $\stackrel{\circ}{ }$ & 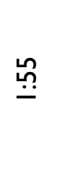 & $\frac{\sigma}{\underline{\underline{\sigma}}}$ & 1 & 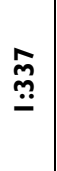 & 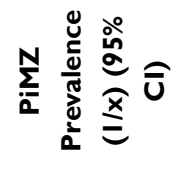 & $\stackrel{m}{q}$ & $\bar{N}$ & $\stackrel{\widetilde{N}}{=}$ \\
\hline
\end{tabular}

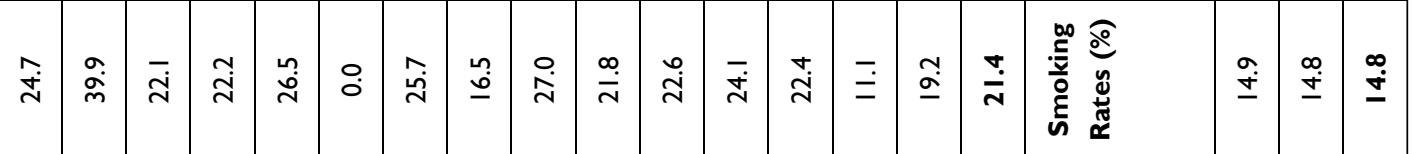

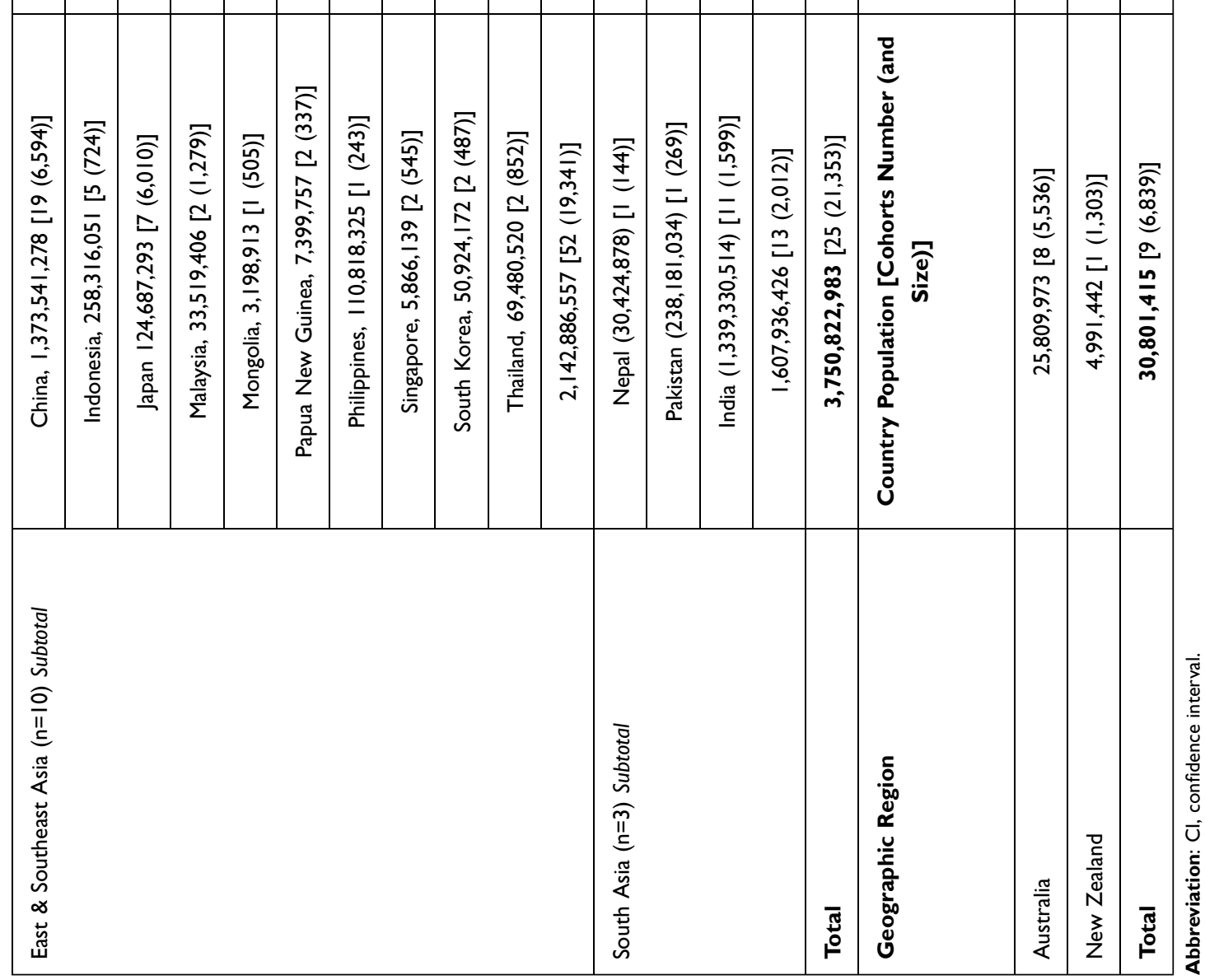



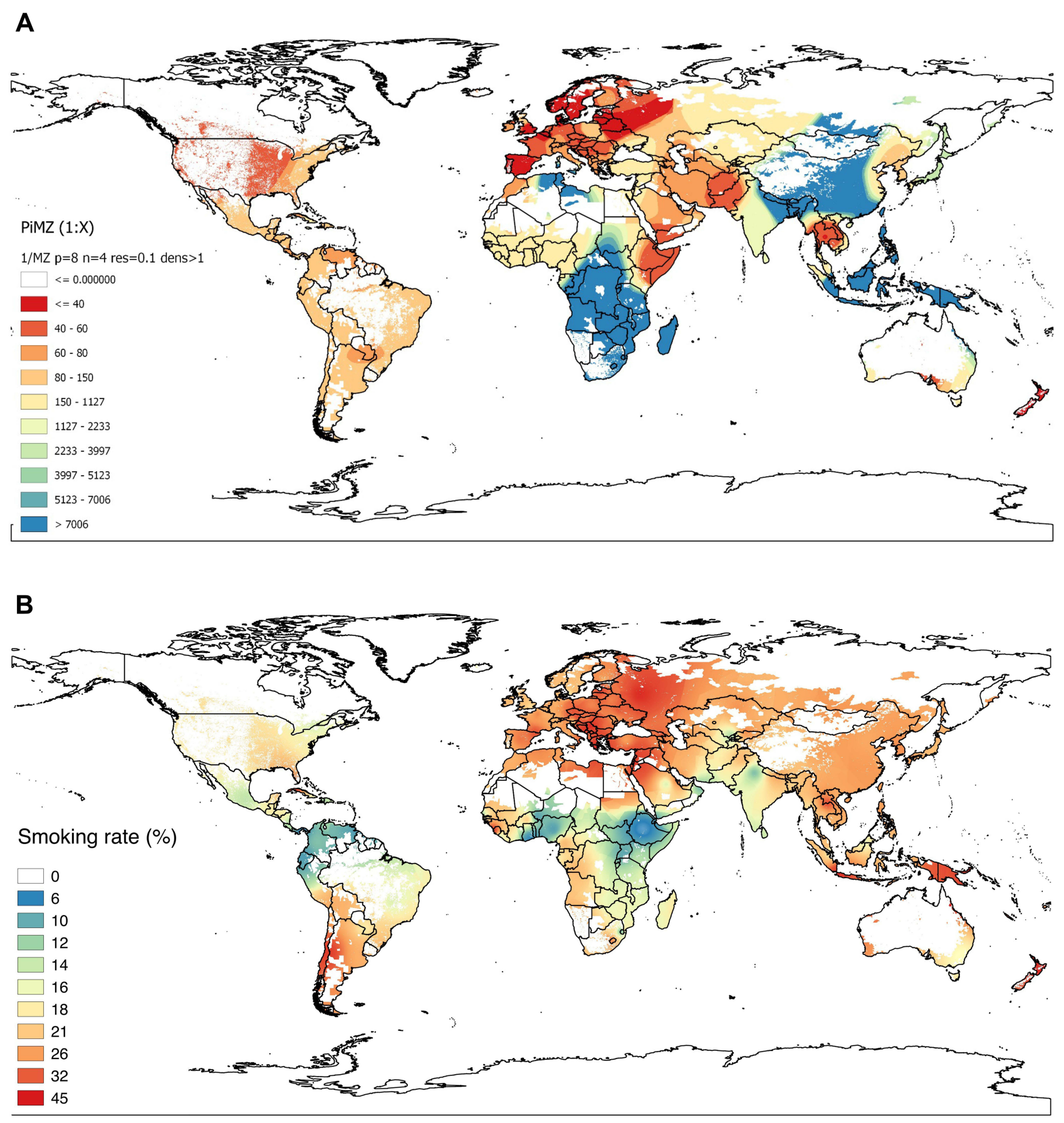

Figure I Inverse distance-weighted (IDW)-interpolation map. (A) of PiMZ prevalence (I/x); (B) of smoking rate (\%) in the world.

Notes: (A) In this map, blue and green tones represent low values (approximately, between I: Infinite and I: I000); brown, intermediate (between <I:I000 and I: I50); light red, high (between <I:150 and I:80), and dark red, very high (between <I:80 and $\leq 1: 40$ ). (B): In this map, blue tones indicate very low rates of smoking $(0 \%-10 \%)$; greenish and light yellow, low rates $(11 \%-20 \%)$, light red shades represent intermediate rates $(>20 \%-30 \%)$, and dark red, very high rates $(>30 \%-45 \%)$. The sparsely populated areas with less than one inhabitant per square kilometer appear shaded in white.

relationship with liver cirrhosis in adults with fatty liver, habitual drinkers of alcoholic beverages and hepatotoxic substance users, although less studied, is also sufficiently documented and recognized. ${ }^{29-32,41}$
Our study found an alarming number of more than thirty-five million MZ subjects in 74 countries out of the 195 in the world with available data. Moreover, our IDWinterpolation map indicates that there may be many more 
$\mathrm{MZ}$ carriers in several geographical regions of Asia and Africa lacking real data. Previous studies have found that among patients diagnosed with COPD the prevalence of the PiMZ genotype ranges from $1 \%$ to $22 \%$., 27,42 According to these percentages of genetic penetrance, up to one-fifth of the estimated 35 million of the MZ carriers from the 74 selected countries (ie, approximately 7 million) will develop COPD.

Our study has some limitations: firstly, our estimates may have some biases primarily due to the non-uniformity of the samples from which the $M Z$ prevalence values derive, the majority from newborns and heterogeneous groups of "healthy unrelated people" that may not be fully representative of the general population. ${ }^{43}$ Secondly, another bias that may have distorted the results is that $\mathrm{MZ}$ prevalence values were only available for less than half of the countries in the world, and that the existing ones are not uniformly distributed, with notable deficiencies in large parts of Asia, Africa or South America, which significantly lowers the precision of the GIS-IDW interpolation.

Smoking, with 1.3 billion tobacco smokers in the world, is considered the main factor inducing the development of COPD in MZ heterozygotes. Overall, the highest smoking rates are in the Balkan region of Europe and Southeast Asia, while American and African countries have lower smoking rates. However, in some individual countries, the global average smoking rates reach very high values, for example: Greece with $42.6 \%$, Serbia with $41.6 \%$, Russia with $40.9 \%$, Indonesia with $39.9 \%$; Chile with $38.0 \%$, etc. In contrast, in many African countries, including Nigeria and Ethiopia, the smoking rate was less than $10 \%$. We observed that the high prevalence of $\mathrm{MZ}$ coincides with high smoking rates in Europe; Western Asia; North America; southern cone of South America; Australia and New Zealand, but the areas of East and West Africa and the north of South America, with high prevalence of $\mathrm{MZ}$, have low rates of smoking. Even though the main risk factor for MZ-related COPD is chronic exposure to tobacco smoke, other risk factors that may be involved in the pathogenesis of COPD in MZ individuals, such as indoor pollution from the use of solid fuels in cooking and heating; outdoor air pollution; exposure to industrial dusts and chemicals, and repeated lower respiratory tract infections in childhood. Remarkably, in many areas of Africa, Central America, South-east Asia and South Asia more than $90 \%$ of rural homes use solid fuel as the primary cooking and/or heating, and this fact could explain the high rate of COPD in these zones. ${ }^{44}$

Interestingly, a recent survey, carried out in patients with AATD included in the AlphaNet's Disease Management Program, showed that $M Z s$ reported a worse health behaviour than PiSZ or PiZZ, including poor exercise habits, obesity and sedentary lifestyle, active smoking prior to the development of lung disease, less engaged to proceed with smoking cessation-related behaviours including seeking information on smoking cessation, using pharmacotherapy for smoking cessation, etc., and this unhealthy behaviour may persist after the diagnosis. $^{45}$ These findings indicate that MZ carriers, despite having a less risky genetic predisposition than ZZs to develop AATD-related diseases, may need an intensification of education and medical interventions aimed at promoting healthy lifestyles after diagnosis. ${ }^{45,46}$

MZ heterozygotes express serum levels of AAT of 11-28 $\mu \mathrm{M} / \mathrm{L}$ (or $62-151 \mathrm{mg} / \mathrm{dL}$ ), which are approximately $60 \%$ of the normal range of MM [20-53 $\mu \mathrm{mol} / \mathrm{L}(102-254)]{ }^{4}$ This means that the vast majority of $\mathrm{MZ}$ heterozygotes express serum levels above the empirically established "protective threshold" of lungs against neutrophil elastase (ie, $11 \mu \mathrm{M} / \mathrm{L}$ or $57 \mathrm{mg} / \mathrm{dL}$ ), a historical value mainly used to indicate augmentation therapy in emphysematous patients with severe AATD. ${ }^{1,47}$ However, a minority of MZs express concentrations very close to it, ${ }^{4,48-50}$ and considering that the circulating AAT of the heterozygous $\mathrm{MZ}$ is a mixture of normal $\mathrm{M}(\sim 80 \%)$ and deficient $\mathrm{Z}(\sim 20 \%)$ proteins, ${ }^{51}$ they may have insufficient $M$ protein to neutralize the abundant amount of serine proteases released during respiratory exacerbations, especially if they are frequent or severe, or if AAT is inactivated by tobacco smoke. In addition, $\mathrm{Z}$ protein polymers from the epithelial lung cells can attract and activate neutrophils, increasing the amount of proteases in the lungs. ${ }^{52}$ However, since AAT is an acute phase reactant whose production can double during inflammation and its local production by lung resident cells can be multiplied up to 11 times, ${ }^{53-55}$ it is assumed that under these circumstances MZ levels may exceed the "protective threshold" reaching sufficient concentration to neutralise neutrophil serine proteases and other inflammatory mediators released by microorganisms and activated cells. Really, the "threshold" value represents a systemic concentration of AAT in serum rather than its level in the alveolar fluid, and thus does not accurately reflect the AAT functional activity into the lungs. ${ }^{42}$ Another factor that may play a significant role in the development of lung emphysema is the gene expression of 
neutrophil elastase that could be increased in MZs, contributing to aggravate the AATD protease/antiprotease imbalance. ${ }^{42}$ Lately, it has been reported that several "rare/ M-like and Z" compound heterozygotes, correctly characterized by gene sequencing, initially were misdiagnosed as PiMZ. ${ }^{56-58}$ For example, in 6 of 103 putative MZs from the Alpha-1 Foundation Research Registry, with serum levels around $15 \mu \mathrm{M}$, performing a gene sequencing with a nextgeneration sequencing (NGS) method showed that they were actually ZZ, SZ, FZ, ZSmunich, ZM2obernburg, and Z/c $0.922 \mathrm{G}>\mathrm{T}$ genotypes. ${ }^{59}$ Thus, the empirically assigned "protective threshold" value, though it may provide some clinical guidance in defining risk, it may do so inaccurately or even erroneously. $^{4}$

\section{Conclusion}

(1) There are an impressive number of $\mathrm{MZ}$ carriers (between $2 \%$ and $4 \%$ of the population of European heritage), living in Europe; America, Australia and New Zealand countries with high smoking rate, and a smaller but not negligible number in other African, Asian and Central and South American countries, where apart from smoking, indoor, outdoor and industrial pollution can play an important role in the development of COPD. (2) The biological mechanisms that underlie increased risk among MZs are only partially known, and therefore more studies are needed to know what the contribution of the genetic defect and of the exogenous factors is, together and separately, in the development of COPD in MZ carriers to know the exact risk that this genotype carries, ideally through reference centers. ${ }^{60}$ (3) Augmentation therapy is not indicated for $\mathrm{MZ}$ carriers, but prevention is essential. (4) Detection of $\mathrm{MZ}$ carriers should encourage doctors to apply preventive measures, which can be crucial to prevent the development of AATD-associated diseases. A doctor who identifies an $\mathrm{MZ}$ carrier must clarify to his patient that although he has a genotype of low risk in itself, the practice of some risky behaviors (especially, smoking and alcoholism) can favor the development of COPD and liver cirrhosis in adulthood, and he must encourage his patient to live a life with healthy habits to prevent the development of diseases associated with AATD.

\section{Disclosure}

CM-G, IB, ID and PB declare that they have no conflicts of interest related to this manuscript. MM has received speaker fees from AstraZeneca, Boehringer Ingelheim, Chiesi, Cipla, GlaxoSmithKline, Menarini, Rovi, Bial,
Sandoz, Zambon, CSL Behring, Grifols and Novartis; consulting fees from AstraZeneca, Boehringer Ingelheim, Chiesi, GlaxoSmithKline, Bial, Gebro Pharma, Kamada, CSL Behring, Laboratorios Esteve, Ferrer, Mereo Biopharma, Palobiofarma SL, Verona Pharma, TEVA, Spin Therapeutics, pH Pharma, Novartis, Sanofi and Grifols and research grants from Grifols.

\section{References}

1. Miravitlles M, Dirksen A, Ferrarotti I, et al. European Respiratory Society statement: diagnosis and treatment of pulmonary disease in a1-antitrypsin deficiency. Eur Respir J. 2017;50:1700610.

2. Seixas S, Marques PI. Known mutations at the cause of Alpha-1 antitrypsin deficiency an updated overview of SERPINA1 variation spectrum. Appl Clin Genet. 2021;14:173-194.

3. de Serres F, Blanco I. Role of alpha-1 antitrypsin in human health and disease. J Intern Med. 2014;276:311-335.

4. Stoller JK, Hupertz V, Aboussouan LS. Alpha-1 antitrypsin deficiency. In: Adam MP, Ardinger HH, Pagon RA, et al., editors. GeneReviews ${ }^{\circledR}$. Seattle: University of Washington, Seattle; 2006:1993-2020.

5. Lomas DA, Evans DL, Finch JT, Carrell RW. The mechanism of $Z \alpha 1$ antitrypsin accumulation in the liver. Nature. 1992;357:605-607.

6. Strnad P, McElvaney NG, Lomas DA. Alpha(1)-antitrypsin deficiency. $N$ Engl J Med. 2020;382:1443-1455.

7. Laurell CB, Eriksson S. The electrophoretic alpha1-globulin pattern of serum in alpha1-antitrypsin deficiency. Scan J Clin Lab Invest. 1963;15:132-140.

8. Fagerhol MK, Hauge HE. Serum Pi types in patients with pulmonary disease. Acta Allergol. 1969;24:107-109.

9. Welch MH, Reinecke ME, Hammarsten JF, Guenter CA. -1 antitrypsin deficiency in pulmonary disease; the significance of intermediate levels. Ann Intern Med. 1969;71:533-537.

10. Talamo RC, Langley CE, Levine BW, Kazemi H. Genetic vs. quantitative analysis of serum -1 antitrypsin. $N$ Engl $J$ Med. 1972;287:1067-1069.

11. Gerblich AA, Kleinerman J, Rynbrandt DJ, Chester EH, Ihrig J. Pi-Z phenotypes in a pulmonary clinic: their prevalence and physiologic state. Am J Clin Pathol. 1978;69:509-513.

12. Kueppers F, Donhardt A. Obstructive lung disease in heterozygotes for -1 antitrypsin deficiency. Ann Intern Med. 1974;80:209-212.

13. Mittman C, Lieberman J, Rumsfeld J. Prevalence of abnormal protease inhibitor phenotypes in patients with chronic obstructive lung disease. Am Rev Respir Dis. 1974;109:295-296.

14. Barnett TB, Gottovi D, Johnson AM. Protease inhibitors in chronic obstructive pulmonary disease. Am Rev Respir Dis. 1975;111:587-593.

15. Cox DW, Hoeppner VH, Levison H. Protease inhibitors in patients with chronic obstructive pulmonary disease: the a- 1 antitrypsin heterozygote controversy. Am Rev Respir Dis. 1976;113:601-606.

16. Shigeoka JW, Hall WJ, Hyde RW, et al. The prevalence of $\alpha-1$ antitrypsin heterozygotes (PiMZ) in patients with obstructive pulmonary disease. Am Rev Respir Dis. 1976;114:1077-1084.

17. Lochon BDV, Lochon C, Fournier M, Martin JP, Derenne JP, Pariente R. Pan-lobular emphysema: relationship with serum $\alpha-1$ antitrypsin levels, Pi phenotype and the HLA system. Nouv Presse Med. 1978;7:1167-1170.

18. Stockley RA. Alpha-1-antitrypsin phenotypes in cor pulmonale due to chronic obstructive airways disease. QJ Med. 1979;48:419-428.

19. Bruce RM, Cohen BH, Diamond EL, et al. Collaborative study to assess risk of lung disease in Pi MZ phenotype subjects. Am Rev Respir Dis. 1984;130:386-390. 
20. Bartmann K, Fooke-Achterrath M, Koch G, et al. Heterozygosity in the Pi-system as a pathogenetic cofactor in chronic obstructive pulmonary disease (COPD). Eur J Respir Dis. 1985;66:284-296.

21. Klasen EC, Biemond I, Laros CD. $\alpha-1$ antitrypsin deficiency and the flaccid lung syndrome: the heterozygote controversy. Clin Genet. 1986;29:211-215.

22. Lieberman J, Winter B, Sastre A. $\alpha-1$ antitrypsin Pi-types in 965 COPD patients. Chest. 1986;89:370-373.

23. Hersh CP, Dahl M, Ly NP, Berkey CS, Nordestgaard BG, Silverman EK. Chronic obstructive pulmonary disease in alpha1-antitrypsin PI MZ heterozygotes: a meta-analysis. Thorax. 2004;59:843-849.

24. Sørheim IC, Bakke P, Gulsvik A, et al. $\alpha 1$-Antitrypsin protease inhibitor MZ heterozygosity is associated with airflow obstruction in two large cohorts. Chest. 2010;138:1125-1132.

25. Molloy K, Hersh CP, Morris VB, et al. Clarification of the risk of chronic obstructive pulmonary disease in alpha-1 antitrypsin deficiency PiMZ heterozygotes. Am J Respir Crit Care Med. 2014;189:419-427.

26. Foreman MG, Wilson C, DeMeo DL, et al. Alpha-1 antitrypsin PiMZ genotype is associated with chronic obstructive pulmonary disease in two racial groups. Ann Am Thorac Soc. 2017;14:1280-1287.

27. Al Ashry HS, Strange C. COPD in individuals with the PiMZ alpha-1 antitrypsin genotype. Eur Respir Rev. 2017;26:170068.

28. Pittschieler K. Liver involvement in alpha-1 antitrypsin-deficient phenotypes PiSZ and PiMZ. Acta Paediatr. 2002;91:239-240.

29. Graziadei IW, Joseph JJ, Wiesner RH, Therneau TM, Batts KP, Porayko MK. Increased risk of chronic liver failure in adults with heterozygous alphal-antitrypsin deficiency. Hepatology. 1998;28:1058-1063.

30. Schaefer B, Mandorfer M, Viveiros A, et al. Heterozygosity for the alpha-1-antitrypsin $Z$ allele in cirrhosis is associated with more advanced disease. Liver Transpl. 2018;24:744-751.

31. Strnad P, Buch S, Hamesch K, et al. Heterozygous carriage of the alpha1-antitrypsin $\mathrm{Pi}$ Z $\mathrm{Z}$ variant increases the risk to develop liver cirrhosis. Gut. 2019;68:1099-1107.

32. Shah RS, Alsuleiman B, Bena J, Stoller JK, Wakim-Fleming J. Alpha-1 antitrypsin deficiency is under-recognized in individuals with cirrhosis undergoing liver transplantation. Eur $J$ Gastroenterol Hepatol. 2020. doi:10.1097/MEG.0000000000002005

33. de Serres FJ. Worldwide racial and ethnic distribution of alpha1-antitrypsin deficiency: summary of an analysis of published genetic epidemiologic surveys. Chest. 2002;122:1818-1829.

34. Blanco I, Bueno P, Diego I, et al. Alpha-1 antitrypsin Pi*Z gene frequency and $\mathrm{Pi}^{*} \mathrm{ZZ}$ genotype numbers worldwide: an update. Int J Chron Obstruct Pulmon Dis. 2017;12:561-569.

35. Blanco I, Bueno P, Diego I, et al. Alpha-1 antitrypsin Pi*SZ genotype: estimated prevalence and number of SZ subjects worldwide. Int J Chron Obstruct Pulmon Dis. 2017;12:1683-1694.

36. Blanco I, Diego I, Bueno P, Pérez-Holanda S, Casas-Maldonado F, Miravitlles M. Prevalence of $\alpha 1$-antitrypsin PiZZ genotypes in patients with COPD in Europe: a systematic review. Eur Respir Rev. 2020;29:200014.

37. Chan-Yeung M, Ashley MJ, Corey P, Maledy H. Pi phenotypes and the prevalence of chest symptoms and lung function abnormalities in workers employed in dusty industries. Am Rev Respir Dis. 1978;117:239-245

38. Beckman G, Beckman L, Mikaelsson B, Rudolphi O, Stjernberg N, Wiman LG. Alpha-1-antitrypsin types and chronic obstructive lung disease in an industrial community in Northern Sweden. Hum Hered. 1980;30:299-306.

39. Banauch GI, Brantly M, Izbicki G, et al. Accelerated spirometric decline in New York City firefighters with $\alpha 1$-antitrypsin deficiency. Chest. 2010;138:1116-1124.

40. Mehta AJ, Thun GA, Imboden $\mathrm{M}$, et al. Interactions between SERPINA1 PiMZ genotype, occupational exposure and lung function decline. Occup Environ Med. 2014;71:234-240.
41. Pons M, Nuñez A, Esquinas C, et al. Utility of transient elastography for screening of liver disease in patients with alpha1-antitrypsin deficiency. J Clin Med. 2021;10:1724.

42. Barjaktarevic I, Miravitlles M. Alpha-1 antitrypsin (AAT) augmentation therapy in individuals with the PI*MZ genotype: a pro/con debate on a working hypothesis. BMC Pulm Med. 2021;21:99.

43. Blanco I. A well-designed/conducted study on alpha-1 antitrypsin epidemiology not quoted. Eur Respir J. 2018;51:1702662.

44. Pathak U, Gupta NC, Suri JC. Risk of COPD due to indoor air pollution from biomass cooking fuel: a systematic review and meta-analysis. Int J Environ Health Res. 2020;30:75-88.

45. Holm KE, Mannino DM, Choate R, Sandhaus RA. Genotype is associated with smoking and other key health behaviors among individuals with alpha-1 antitrypsin deficiency-associated lung disease. Respir Med. 2018;143:48-55.

46. Franciosi AN, Alkhunaizi MA, Woodsmith A, et al. Alpha-1 antitrypsin deficiency and tobacco smoking: exploring risk factors and smoking cessation in a registry population. COPD. 2021;18 (1):76-82.

47. Crystal RG. Alpha 1-antitrypsin deficiency, emphysema, and liver disease. Genetic basis and strategies for therapy. J Clin Invest. 1990;85:1343-1352.

48. Bornhorst JA, Greene DN, Ashwood ER, Grenache DG. Alpha1antitrypsin phenotypes and associated serum protein concentrations in a large clinical population. Chest. 2013;143:1000-1008.

49. Ferrarotti I, Thun GA, Zorzetto M, et al. Serum levels and genotype distribution of alpha1-antitrypsin in the general population. Thorax. 2012;67:669-674.

50. Strange C, Monk R, Schwarz L, Walker D, Kumbhare S, Bieko T. The United States Alpha-1 foundation research registry: genesis, impact and future. COPD. 2015;12(Suppl 1):42-45.

51. Donato LJ, Karras RM, Katzmann JA, Murray DL, Snyder MR. Quantitation of circulating wild-type alpha-1-antitrypsin in heterozygous carriers of the $\mathrm{S}$ and $\mathrm{Z}$ deficiency alleles. Respir Res. 2015;16:96.

52. Alam S, Li Z, Atkinson C, Jonigk D, Janciauskiene S, Mahadeva R. $\mathrm{Z} \alpha 1$-antitrypsin confers a proinflammatory phenotype that contributes to chronic obstructive pulmonary disease. Am J Respir Crit Care Med. 2014;189:909-931.

53. Janciauskiene SM, Bals R, Koczulla R, Vogelmeier C, Köhnlein T, Welte $\mathrm{T}$. The discovery of $\alpha 1$-antitrypsin and its role in health and disease. Respir Med. 2011;105:1129-1139.

54. Ellis P, Turner A. What do Alpha-1 antitrypsin levels tell us about chronic inflammation in COPD? Arch Bronconeumol. 2020;56 (2):72-73.

55. Janciauskiene S, DeLuca DS, Barrecheguren $M$, Welte $T$, Miravitlles M. Serum levels of Alpha1-antitrypsin and their relationship with COPD in the General Spanish Population. Arch Bronconeumol. 2020;56:76-83.

56. Matamala N, Lara B, Gómez-Mariano G, et al. miR-320c regulates SERPINA1 expression and is induced in patients with pulmonary disease. Arch Bronconeumol. 2021;57(4):457-463.

57. Matamala N, Lara B, Gomez-Mariano G, et al. Characterization of novel missense variants of SERPINA1 gene causing Alpha-1 antitrypsin deficiency. Am J Respir Cell Mol Biol. 2018;58:706-716.

58. Martin T, Miravitlles M, Tello Furtado S. A PI*MS is not always a PI*MS. An example of when genotyping for alpha-1 antitrypsin deficiency is necessary. Pulmonology. 2021;27:257-276.

59. Foil KE, Blanton MG, Sanders C, et al. Sequencing Alpha-1 MZ individuals shows frequent biallelic mutations. Pulm Med. 2018;2018:2836389.

60. Miravitlles M, Nuñez A, Torres-Durán M, et al. The importance of reference centers and registries for rare diseases: the example of Alpha-1 antitrypsin deficiency. COPD. 2020;17(4):346-354. 


\section{Publish your work in this journal}

The International Journal of COPD is an international, peer-reviewed journal of therapeutics and pharmacology focusing on concise rapid reporting of clinical studies and reviews in COPD. Special focus is given to the pathophysiological processes underlying the disease, intervention programs, patient focused education, and self management protocols. This journal is indexed on PubMed Central, MedLine and CAS. The manuscript management system is completely online and includes a very quick and fair peer-review system, which is all easy to use. Visit http://www.dovepress.com/testimonials.php to read real quotes from published authors.

Submit your manuscript here: https://www.dovepress.com/international-journal-of-chronic-obstructive-pulmonary-disease-journal 